\title{
Immunoelectron microscopic localisation of transforming growth factor alpha in rat colon
}

\author{
R Pérez-Tomás, X Culleré, M Asbert, C Díaz-Ruiz
}

\begin{abstract}
Transforming growth factor alpha (TGF $\alpha$ ) is a polypeptide, which binds to the epidermal growth factor receptor to carry out its function related to cell proliferation and differentiation. The ultrastructural localisation of TGF $\alpha$ was studied in both the proximal and the distal colon. The columnar cells, lining the surface epithelium of the proximal colon, showed a strong immunoreactivity in the polyribosomes and in the interdigitations of the lateral membrane. The columnar cells of the crypts and the goblet cells in both the proximal and the distal colon showed the immunostaining in the cis and trans cisternae of the Golgi apparatus. TGF $\alpha$ seems to be processed differently in the surface columnar cells and in the crypt columnar cells and goblet cells. Moreover, it probably has different roles in proliferation and differentiation.

(Gut 1994; 35: 1086-1089)
\end{abstract}

Transforming growth factor alpha (TGF $\alpha$ ) is a 50 amino acid polypeptide structurally and functionally related to epidermal growth factor, which binds to the epidermal growth factor/TGF $\alpha$ receptor. ${ }^{1}$ TGF $\alpha$ was originally isolated from retrovirally transformed 3 T 3 cells $^{2}$ and has also been shown to be expressed by chemically transformed cells. ${ }^{34}$ TGF $\alpha$ is synthesised as a larger precursor of 159 or 160 amino acids, which is an integral membrane glycoprotein (pro TGF $\alpha$ ). The mature form is released by proteolytic cleavage of pro TGF $\alpha .{ }^{56}$ Different forms of pro TGF $\alpha$ have been shown to accumulate in the membranes of growth factor producing cell lines. Solubilised precursors induce tyrosine autophosphorylation of the epidermal growth factor/TGF $\alpha$ receptor in intact receptor overexpressing cells, and anchorage independent growth of NRK fibroblasts. ${ }^{7}$ This membrane anchored growth factor precursor may have an important role in developmental processes that require cell-cell interactions that are not compatible with the diffusible nature of secretory factors. TGF $\alpha$ mRNA and protein has been described during embryonic development ${ }^{89}$ and in several adult tissues including pituitary, ${ }^{10}$ brain, ${ }^{11}$ macrophages, ${ }^{12}$ skin keratinocytes, ${ }^{13}$ kidney, ${ }^{14}$ and colon. ${ }^{15}$

Up to now, a morphological study of the subcellular localisation of TGF $\alpha$ and its secretion has been lacking. To consider this issue, we studied the ultrastructural distribution of TGF $\alpha$ protein in normal rat colon, based on our previous study at the light microscopy level. ${ }^{15}$ Our results support a possible role for TGF $\alpha$ in the modulation of proliferation and differentiation of the intestinal epithelium.

\section{Methods}

TISSUES

Adult Sprague Dawley rats weighing 150-320 g were killed by cervical dislocation. The abdominal wall was opened and the proximal and distal colon were dissected out intact.

\section{IMMUNOELECTRON MICROSCOPY}

Small pieces of proximal and distal colon were fixed in a mixture of $2 \%$ paraformaldehyde and $1 \%$ glutaraldehyde in phosphate buffered saline (PBS) for two hours at $4^{\circ} \mathrm{C}$. After washing in PBS the specimens were incubated in $50 \mathrm{mM} \mathrm{NH} \mathrm{NH}_{4} \mathrm{Cl}$ in PBS for 60 minutes to block aldehyde residues. The specimens were dehydrated in a graded ethanol series and embedded in Lowicryl K4M. Ultrathin sections were cut on a Reichert-Imy ultracut ultramicrotome using a diamond knife, and mounted on a nickel grid coated with formvar and carbon.

Labelling of the immunoreactive sites was achieved by indirect on grid immunogold staining as previously described. ${ }^{16}$ The sections were incubated on a drop of normal goat serum (diluted 1:30 in PBS pH 7.2, 0.1\% bovine albumin, $0.01 \%$ sodium azide $(\mathrm{NaAz})$ ) for 30 minutes to block the background and for two hours at room temperature in mouse monoclonal anti-TGF $\alpha$ ((diluted $2 \mu \mathrm{g} / \mathrm{ml})$ in PBS-bovine serum albumin-NaAz; Oncogene Science, ref GF10). The anti-TGF $\alpha$ antibody recognises a human TGF $\alpha$ epitope (residues 34-50) and it does not crossreact with epidermal growth factor. ${ }^{17}$ The sections were washed on five drops of PBS and the primary antibodies were localised using colloidal gold (10 nm diameter) labelled goat antimouse IgG (diluted 1:60 in PBS-bovine serum albumin-0.05\% Tween 20; Sigma, ref G2272) for one hour at room temperature. The sections were washed on drops of PBS and distilled water and stained with $2 \%$ uranyl acetate and lead citrate. Electron micrographs were taken using a Philips 301 electron microscope.

\section{NEGATIVE CONTROL}

The following were included as negative controls: (a) primary incubation with PBSbovine serum albumin- $\mathrm{NaAz}$, (b) primary 


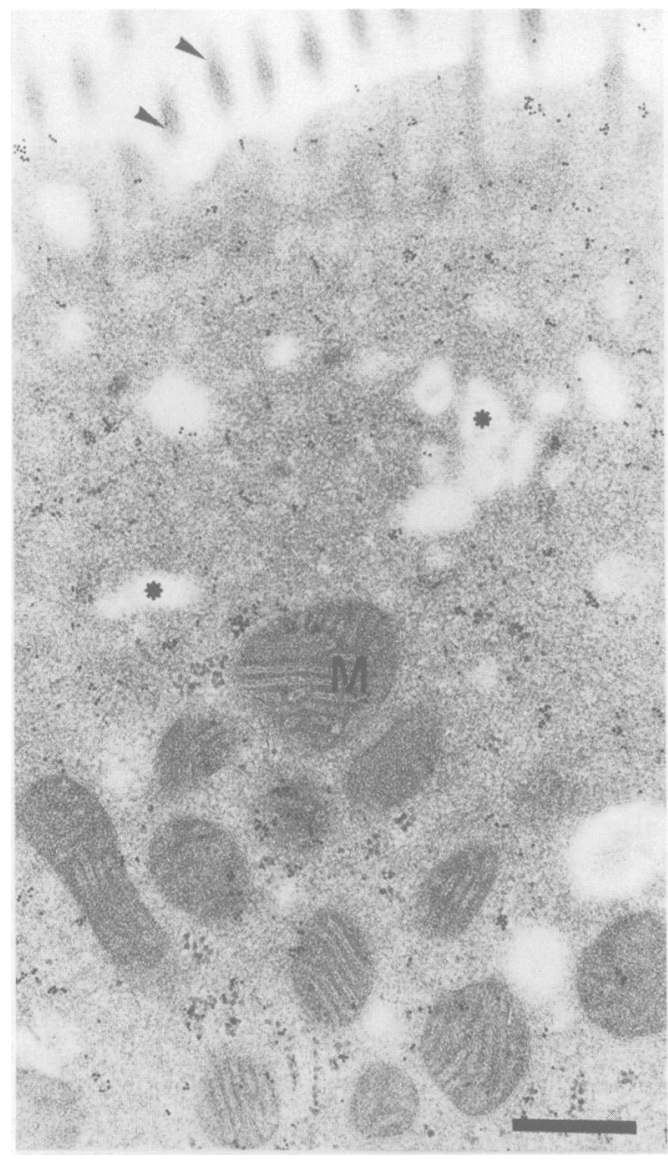

Figure 1: Electron micrograph of surface columnar cell in the proximal colon. An intense labelling with $10 \mathrm{~nm}$ gold particles is seen distributed throughout the cytoplasm. Mitochondria (M), microvilli (arrowhead), and clear vesicle (asterisk) are shown. (Immunogold test; bar represents $0.35 \mu \mathrm{m}$.)

incubation with anti-TGF $\alpha(2 \mu \mathrm{g} / \mathrm{ml})$ preabsorbed with rat TGF $\alpha(30 \mu \mathrm{g} / \mathrm{ml}$, fragment 1-50, Bachem, ref $\mathrm{H}-5545)$ for 24 hours at $4^{\circ} \mathrm{C}$.

\section{Results}

The proximal and the distal colon, lined by columnar cells, showed abundant microvilli projecting from the apical plasma membrane. Membrane bound vesicles were commonly seen

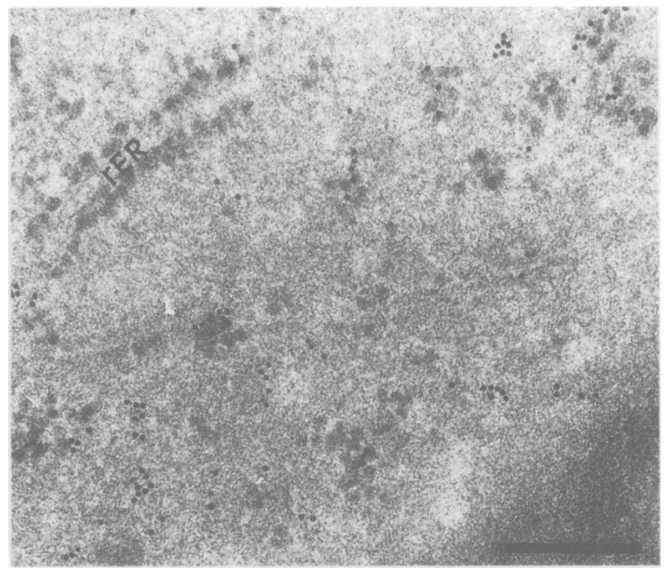

Figure 2: Electron micrograph of surface columnar cell in the proximal colon. TGF $\alpha$ immunoreactivity is associated with the polyribosomes. Note that the rough endoplasmic reticulum (rER) did not show any staining. (Immunogold test; bar represents $0.35 \mathrm{~mm}$.

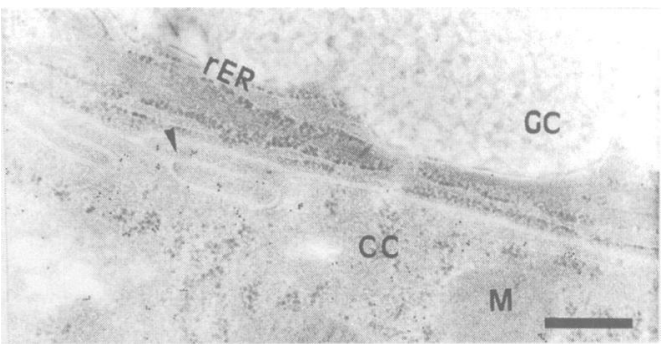

Figure 3: Electron micrograph of surface columnar cell (CC) in the proximal colon. TGF $\alpha$ immunoreactivity is localised with $10 \mathrm{~nm}$ gold particles in the interdigitations of the lateral membranes and in the polyribosomes. No immunoreactivity was seen in the neighbouring goblet cell (GC). Mitochondria (M), interdigitations (arrowhead), and rough endoplasmic reticulum (rER) are shown. (Immunogold test; bar represents $0.35 \mu \mathrm{m}$.)

in the web region. A Golgi complex, small clear vesicles, and abundant mitochondria were seen in the supranuclear region. Both smooth and rough endoplasmic reticulum could also be seen through the cytoplasm. The nucleus was located in the basal third of the cell.

Positive staining with the anti-TGF $\alpha$ antibody was seen in the columnar cells of the proximal colon and the strongest reaction confined to the cytoplasm (Fig 1), was regularly associated with polyribosomes (Fig 2). Nuclei, mitocondria, smooth and rough endoplasmic reticulum, and small clear vesicles did not show any immunoreactivity. Positive immunoreactivity was also identified in the interdigitations of the lateral membranes (Fig 3). Furthermore, hardly any immunoreactivity was seen on the microvilli of the columnar cells.

In the proximal colon, the crypts are longer than in other parts of the colon. The upper two thirds are lined by columnar and goblet cells. The lower part is covered by goblet cells. The distal colon has shorter crypts. The upper part is lined by columnar and goblet cells. The lower part is mainly covered by goblet cells and a smaller number of columnar cells. The columnar cells of the crypts in both the proximal and the distal colon showed positive staining with the anti-TGF $\alpha$ antibody in the cisternae of the Golgi apparatus (Fig 4). We could not find any immunoreactivity in the cytoplasm.

In both the proximal and the distal colon, the goblet cells are characterised by mucous granules occupying the apical two thirds of the cell. The nucleus is located in the basal

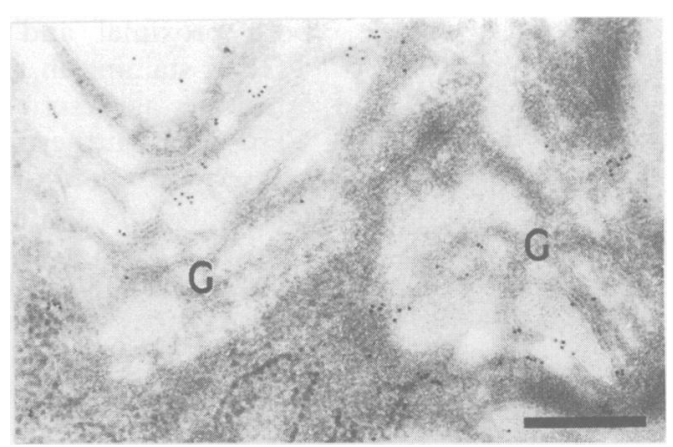

Figure 4: Electron micrograph of crypt columnar cell in the distal colon. TGF $\alpha$ antibody shows an intense labelling in the cisternae membranes of the Golgi apparatus $(G)$. (Immunogold test; bar represents $0.35 \mu \mathrm{m}$.) 


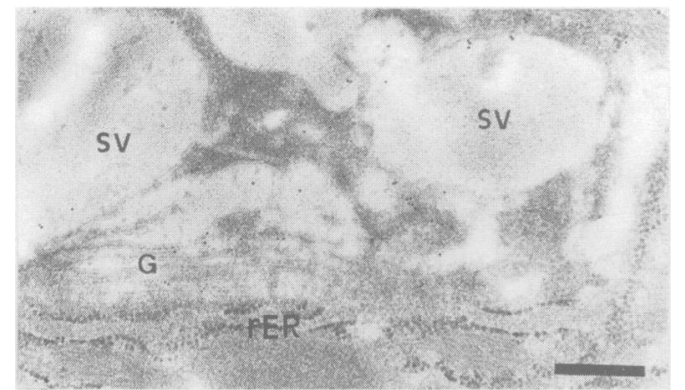

Figure 5: Electron micrograph of crypt goblet cell of proximal colon. Immunoreaction for TGF $\alpha$ is seen in the cisternae and the secretory vesicles (SV) of the Golgi apparatus (G). Rough endoplasmic reticulum (rER). (Immunogold test; bar represents $0.035 \mu \mathrm{m}$.)

region of the cell and a Golgi complex is usually seen in the supranuclear region. The immunoreactivity was mainly located in the Golgi apparatus of both cis and trans cisternaes. The gold particles were confined to the cisternae membranes (Figs 5 and 6). The mucous granules were also heavily labelled with gold particles (Fig 7).

\section{Discussion}

The intestinal epithelium is a very dynamic tissue, in which cells migrate distally along the crypt-villus axis and the capacity for proliferation is lost. Sophisticated, differentiated, absortive, and digestive functions are progressively acquired. TGF $\alpha$ may have a role in colonic mucosal proliferation and differentiation. We report here, for the first time, the ultrastructural identification of TGF $\alpha$ in the proximal and distal rat colon.

TGF $\alpha$ mRNA in CHO cells (Chinese hamster ovary fibroblast) is processed in the rough endoplasmic reticulum and Golgi apparatus, and anchored to the plasmatic membrane. ${ }^{18}$ We found, however, the specific immunostaining in the polyribosomes of the surface columnar cells of the proximal colon. This localisation could suggest that the coding sequence of the TGF $\alpha$ mRNA has been processed by alternate splicing of the gene in the surface columnar cells. The alternate splicing of the TGF $\alpha$ mRNA has been reported before in the brain. ${ }^{19}$ Some cell lines such as A375, FeSV/FRE, ${ }^{16}$ and SW620 (colon adenocarcinoma) showed a high synthesis of TGF $\alpha^{20}$ and displayed a cytoplasmic staining, as we described in surface columnar cells. On the other hand, columnar cells in both proximal and distal crypts presented TGF $\alpha$ staining in the cisternae of the Golgi apparatus as described by Teixidó et al ${ }^{18}$ in $\mathrm{CHO}$ cells. Furthermore, the apical membrane of both surface and crypt columnar cells did not show gold particles label suggesting that the TGF $\alpha$ precursor is not anchored in the apical membrane in those cell types. This finding may be supported by the experiments of Choudry et al ${ }^{21}$ and Barnes et al .22 They identified an endopeptidase- 2 in the intestinal brush border, which hydrolysed the TGF $\alpha$ (this enzyme degraded about $30 \mathrm{nmol}$ of $\mathrm{h}=\mathrm{TGF} \alpha / \mathrm{h}$ per $\mathrm{mg}$ of protein), and this may explain the absence of staining in the luminal

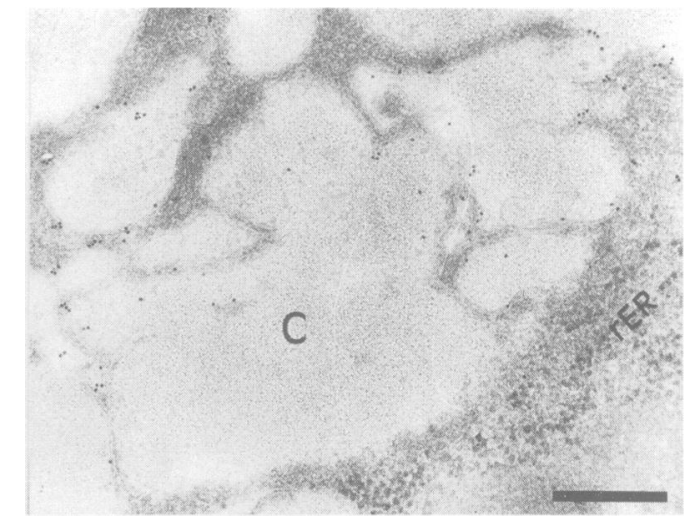

Figure 6: Electron micrograph of crypt goblet cell of distal colon. Note that the cisternae (C) of the Golgi apparatus were swollen with a hypotonic buffer to clarify that the

labelling is mainly located in the cisternae membranes and not in the lumen of the cisternae. Rough endoplasmic reticulum (rER). (Immunogold test; bar represents $0.35 \mu \mathrm{m}$.)

surface. We also found, however, some label associated with the interdigitations of the lateral membrane in the surface and crypt columnar cells. In this case, TGF $\alpha$ could be functioning as a type of receptor or interacting with the epidermal growth factor/TGF $\alpha$ receptor on a neighbouring cell, having a role that requires discrete cell-cell interactions, not compatible with release of the soluble factor. Many studies have been performed on the presence of epidermal growth factor/TGF $\alpha$ receptor in colon epithelium in the adult rodent. ${ }^{24}$ Thus, the influence of TGF $\alpha$ in the colonic mucosa may regulate the balance between proliferation and differentiation by means of binding to epidermal growth factor/TGF $\alpha$ receptor. ${ }^{25}$

Goblet cells in the proximal and distal colon showed the immunoreactivity located in the Golgi apparatus and in the mucous granules. This suggests TGF $\alpha$ must be secreted by goblet cells and also bind to epidermal growth

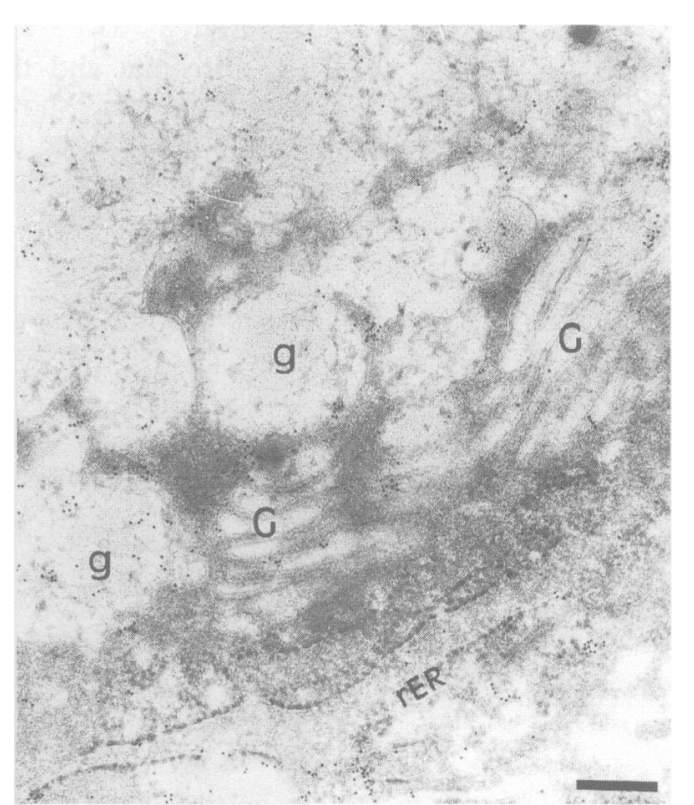

Figure 7: Electron micrograph of crypt goblet cell of distal colon. Immunostaining for TGF $\alpha$ is localised to the membranes of the cisternae and the mucous granules (g) of the Golgi apparatus $G$ ). Rough endoplasmic reticulum (rER). (Immunogold test; bar represents $0.35 \mathrm{~mm}$.) 
factor/TGF $\alpha$ receptor, present in colon epithelium, to induce its biological effects. A recent study reported the association of epidermal growth factor with other proteins in high molecular weight complexes in human milk. ${ }^{26}$ Like epidermal growth factor, TGF $\alpha$ secreted in the mucous granules of the goblet cells could be associated with other glycoproteins to prevent its hydrolysation by endopeptidase 2 .

Therefore, columnar and goblet cells may make distinctive and unequal contributions to overall epithelial production of TGF $\alpha$.

The colonic epithelium is a rapidly proliferating organ that completely renews itself on a weekly basis. ${ }^{27}$ On the other hand, neoplasia of the normal colonic epithelium goes through ordered stages, first to adenomatous then to malignant change. Epidermal growth factor/ TGF $\alpha$ receptor and TGF $\alpha$ production have been individually detected in colon carcinomas and in numerous colon cancer cell lines. ${ }^{28} 29$ Coexpression of TGF $\alpha$ and epidermal growth factor receptor and growth stimulation by TGF $\alpha$ has also been shown in multiple colon cancer cell lines, and TGF $\alpha$ has been proposed as an autocrine growth factor in colon cancer. Processing of pro TGF $\alpha$ in neoplastic cells is generally inefficient and many cell types also secrete large forms of TGF $\alpha$ in varying proportions. ${ }^{30}$ Some of these larger species correspond to the extracellular domain of pro TGF $\alpha$, which has been heterogeneously glycosilated through the addition of both $\mathrm{N}$ and $\mathrm{O}$ linked carbohydrate. ${ }^{31} 33$

In this study we provide evidence of TGF $\alpha$ presence in normal rat colon. Its different subcellular distribution, depending on the type of cell, could be explained by distinct processing pathways, somewhat similar to those found in neoplastic cells.

In summary, we report here for the first time, the identification of TGF $\alpha$ at ultrastructural level in normal rat colon, where it did not act as a transforming factor. The subcellular localisation of TGF $\alpha$ in neoplastic tissues and its comparison with the distribution in normal tissues need to be considered to identify distinct secretion mechanisms of TGF $\alpha$ and therefore its different effects in proliferation and differentiation.

This work was supported by the grant SAL 90-0320 from the 'Dirección General de Investigación Científica y Técnica'. Carmen Diaz is recipient of a FPI fellowship from the 'Ministerio de Educación y Ciencia'. We gratefully acknowledge the excellent technical assistance of Alumudena Garcia, Eva Sánchez y Nuria Cortadellas.

1 Todaro GJ, Fryling C, DeLarco JE. Transforming factors produced by certain tumor cells: polypeptides that interact with epidermal growth factor receptors. Proc Natl Acad Sci USA 1980; 77: 5258-62.

2 DeLarco JE, Todaro GJ. Growth factors from murine sarcoma virus-transformed cells. Proc Natl Acad Sci USA coma virus-transfo.

3 Lee W, Raymond VW, Tsao M, Lee DC, Earp HS, Grisham JW. Clonal cosegregation of tumorigenicity with overexpression of $\mathrm{c}$-myc and transforming growth factor $\alpha$ genes in chemically transformed rat liver epithelial cells. Cancer Res 1991; 51: 5238-44.

4 Pérez-Tomás R, Mayol X, Culleré X, Diaz C, Domingo J. Transforming growth factor- $\alpha$ in rat experimental hepatocarcinogenesis. Histol Histopathol 1992; 7: 457-62.

5 Massagué J. Transforming growth factor $\alpha . \mathcal{F}$ Biol Chem 1990; 265: 21393-6.
6 Derynck R. Transforming growth factor alpha. Cell 1988; 54: 593-5.

7 Brachmann R, Lindquist PB, Magashima $M$, Kohr W, Lipari T, Napier M, et al. Transmembrane TGF $\alpha$ precursors activate $\mathrm{EGF/TGF} \alpha$ receptor. Cell 1989; 36: 691-700.

8 Lee DC, Rochford R, Todaro GJ, Villareal LP. Developmental expression of rat transforming factor a mRNA. Mol Cel Biol 1985; 5: 3644-6.

9 Brown PI, Lam R, Lakshmanan J, Fisher DA. Transforming growth factor alpha in developing rats. Am $\mathcal{F}$ Physiol 1990; 259: E256-60.

10 Kobrin MS, Samsoondar J, Kudlow JE. $\alpha$-Transforming growth factor secreted by untransformed bovine anterior pituitary cells in culture. Identification using a sequencespecific monoclonal antibody. F Biol Chem 1986; 261: specific mon

11 Wilcox JN, Derynck R. Localization of cells synthesizing transforming growth factor-alpha mRNA in the mouse brain. F Neurosci 1988; 8: 1901-4

12 Madtes DK, Raines EW, Sakariassen KS, Assoian RK, Sporn MB, Bell GI, et al. Induction of transforming growth factor- $\alpha$ in activated human alveolar macrophages. Cell 1988; 53: 285-93.

13 Coffey RJ Jr, Derynck R, Wilcox JN, Bringman JS, Goustin AS, Moses HL, et al. Production and autoinduction of transforming growth factor- $\alpha$ in human keratinocytes. Nature 1987; 328: 817-20.

14 Diaz C, Pérez-Tomás $R$, Culleré $\mathrm{X}$, Domingo J. Immunohistochemical localization of transforming growth factor-alpha and epidermal growth factor receptor in the mesonephros and metanephros of chicken. Cell in the mesonephros and
Tissue Res 1993; 271: 3-8.

15 Pérez-Tomás R, Culleré X, Diaz C. Immunohistochemical localization of transforming growth factor $\alpha$ in developing rat colon. Gastroenterology 1993; 104: 789-95.

16 Varndell IM, Tapia FJ, Probert L, Buchan AMJ, Gu J, De Mey J, et al. Immunogold staining procedure for the localisation of regulatory peptides. Peptides 1982; 3: 259-72.

17 Sorvillo JM, McCarmack ES, Yanez L, Valenzuela D, Reynolds FH Jr. Preparation and characterization of monoclonal antibodies specific for human transforming growth factor $\alpha$. Oncogene $1990 ; 5: 377-86$.

18 Teixidó J, Wong ST, Lee Dc, Massagué J. Generation of transforming growth factor- $\alpha$ from the cell surface by an
O-glycosilation-independent multistep process. $\mathcal{F}$ Biol O-glycosilation-independe

19 Kudlow JE, Leung WC, Kobrin MC, Paterson AJ, Asa SL. Transforming growth factor- $\alpha$ in the mammalian brain. f Biol Chem 1989; 264: 3880-3.

20 Hanauske AR, Buchok J, Scheithauer W, Von Hoff DD. Human colon cancer cell lines secrete $\alpha$ TGF-like activity. Br f Cancer 1987; 55: 57-9.

21 Choudry Y, Kenny AJ. Hydrolysis of transforming growth factor- $\alpha$ by cell surface peptidases in vitro. Biochem $\mathcal{F}$ 1991; 280: 57-60.

22 Barnes K, Ingram J, Kenny AJ. Protein of the kidney microvillar membranes. Biochem 7 1989; 264: 335-46.

23 Weaver LT, Gonnella PA, Israel EJ, Walker WA. Uptake and transport of epidermal growth factor by the small intestinal epithelium of the fetal rat. Gastroenterology 1990 ; 98: 828-37.

24 Koretz K, Schlag P, Möller P. Expression of epidermal growth factor receptor in normal colorectal mucosa, adenoma, and carcinoma. Virchows Arch A Pathol Anal Anat Histopathol 1990; 416: 343-9.

25 Koyama SY, Podolsky DK. Differential expression of transforming growth factor $\alpha$ and $\beta$ in rat intestinal epithelial cells. F Clin Invest 1989; 83: 1768-73.

26 Schaudies RP, Grimes H, Wray HL, Koldovsky O. Identification and partial characterization of multiple forms of biologically active EGF in rat milk. Am $\mathcal{f}$ Physiol 1990; 259: G1059-61.

27 Potten CS, Kellet M, Roberts SA, Rew DA, Wilson GD. Measurement of in vivo proliferation in human colorectal Measurement of in vivo proliferation in human colorectal
mucosa using bromodeoxyuridine. Gut 1992; 33: 71-8.

28 Ziober BL, Wilson JKV, Hymprey LE, Childress-Fields K, Brattain MG. Autocrine transforming growth factor- $\alpha$ is associated with progression of transformed properties in human colon cancer cells. $\mathcal{F}$ Biol Chem 1993; 268: 691-8.

29 Modjthahedi N, Haddada H, Lamonerie T, Lazor E, Lavialle C, Brison O. TGF $\alpha$ production correlates with tumorigenicity in clones of the SW613-S human colon carcinoma cell line. Int f Cancer 1992; 92: 483-90.

30 Seroogy K, Han VJM, Lee DC. Regional expression of transforming growth factor- $\alpha$ mRNA in the rat control nervous system. Neurosci Lett 1991; 125: 141-5.

31 Bringman TS, Lindquist PB, Derynck R. Different transforming growth factor- $\alpha$ species are derived from a transforming growth factor- $\alpha$ species are derived from a glycosylated and palmytoyla
cursor. Cell $1987 ; 48: 429-40$.

32 Ignotz RA, Kelly B, Davies J, Massagué J. Biologically active precursor for transforming growth factor type $\alpha$ released by retrovirally transformed cells. Proc Natl Acad Sci USA 1986; 83: 2228-32.

33 Luetteke NC, Michalopoulos GK, Teixidó J, Gilmore R, Massagué J, Lee DC. Characterization of high molecular weight transforming growth factor $\alpha$ produced by rat hepatocellular carcinoma cells. Biochemistry 1988; 27: 6487-94. 